\title{
Immunophenotypes of lymphocytes in prospectively followed up human papillomavirus lesions of the
} cervix

\author{
M VÄYRYNEN,*K SYRJÄNEN,† R MÄNTYJÄRVI, ‡ O CASTRÉN,* AND \\ S SAARIKOSKI* \\ From the Departments of *Gynaecology and Obstetrics, †Pathology, and $\ddagger$ Clinical Microbiology, \\ University of Kuopio, Kuopio, Finland
}

SUMMARY From 1981286 women were prospectively followed up for a mean (SD) of 16 (14) months for established infection with human papillomavirus (HPV) with or without coexistent cervical intraepithelial neoplasia (CIN). The in situ immunocompetent cell infiltrates in 263 cervical punch biopsy specimens from these women were phenotypically identified by the avidinbiotin peroxidase complex (ABC) technique using monoclonal antibodies Leu-10, OKT-3, OKT-4, and OKT-8. Leu-10 ${ }^{+}$B lymphocytes far outnumbered the OKT $-3^{+}$T lymphocytes in all types of HPV lesions (flat, inverted, and papillomatous condylomas of the cervix). The ratio of OKT $-4^{+}$to OKT $-8^{+}$(T helper to T suppressor cells) was slightly reduced in HPV lesions with more severe CIN and correlated positively with the intensity of the immunocompetent cell infiltrate. The ratio of OKT $-4^{+}$to OKT $-8^{+}$cells was highest in the $47(28 \cdot 8 \%)$ patients with HPV lesions that regressed during follow up, somewhat lower in the $85(52 \cdot 1 \%)$ with persistent lesions, and lowest in the 31 $(19 \cdot 1 \%)$ with lesions showing clinical progression. The results are discussed in terms of the proposed immune surveillance functions attributed to immunocompetent cells in situ according to the mucosal associated lymphatic tissue (MALT) concept. The conclusion drawn is that a dynamic balance between the immunoregulatory cells and their subtypes is a prerequisite for the proper handling of intracellular infections of the mucosa, including that with HPV.

\section{Introduction}

The concept that human papillomavirus (HPV) caused entirely innocuous human tumours (squamous cell papillomas and warts) has recently been reapprised. ${ }^{1-6}$ Pertinent new data have been provided by the recent reports on the common association of HPV lesions of the uterine cervix (the flat, inverted, and papillomatous condylomas) with cervical intraepithelial neoplasia (CIN), ${ }^{1379-11} 13$ the malignant transition of HPV lesions elsewhere in the body, ${ }^{46}$ the epidemiological risk factors shared by cervical infection with HPV and squamous cell carcinoma of the cervix (both of which have been shown to be sexually transmitted), 14612 the immunohistochemical detection of HPV structural proteins (or viral antigens) in CIN lesions, ${ }^{125}$ and finally by the DNA hybridisation experiments showing HPV 16

Address for reprints: Dr K Syrjänen, Department of Pathology, University of Kuopio, POB 6, SF-70211 Kuopio 21, Finland

Accepted for publication 11 August 1984 and 18 DNA in invasive cervical cancer ${ }^{8}$ Despite evidence suggesting HPV as a causative agent of squamous cell carcinomas of the cervix and other sites in man, the final proof is still awaited because of the lack of prospective data on the natural history of the HPV, such as the formation of cancer from a preexisting HPV lesion..$^{6714}$ In the same way, the factors that determine whether an HPV lesion will regress, persist, or progress are poorly understood. ${ }^{6}$

HPV lesions, particularly warts, are recognised as being more common in immunosuppressed patients than in healthy people. ${ }^{15-20}$ Furthermore, cutaneous HPV lesions are also known to disappear spontaneously, that is, they regress and show an intense inflammatory cell infiltration. ${ }^{16} 1721-24$ This observation led to the conclusion that immune reactivity of the host would appreciably contribute to infectivity and the clinical course of infections with HPV in man. ${ }^{17}$ Indeed, both humoral and cell mediated immunity have been shown in a variety of infections with HPV. 161722 25-28

In HPV lesions of the uterine cervix, these immune 
mechanisms have so far been poorly identified, although some recent data suggest that local immune reactivity against HPV infections of the cervix might also exist, ${ }^{29-31}$ and some preliminary analyses of the in situ immunocompetent cell infiltrates have been published. ${ }^{14} 293132$ According to our tentative results of immunophenotyping the T cell subsets in $65 \mathrm{HPV}$ lesions of the cervix followed up for a shorter period, some changes in the ratio of OKT $-4^{+}$to OKT- $8^{+}$(T helper to $\mathrm{T}$ suppressor cells) occurred in lesions with different clinical courses. ${ }^{14}$

The report published here is a direct extension of these studies and gives data on the phenotypic identification (with monoclonal antibodies Leu-10, OKT-3, OKT-4, and OKT-8) of the immunocompetent cells in situ in HPV lesions of the cervix in 286 women studied prospectively for a mean (SD) of 16 (14) months.

\section{Patients, materials, and methods}

We investigated 286 consecutive women who were currently included in a prospective study of HPV lesions of the cervix, which was started in 1981. These women were invited to participate in the prospective study if their routine cervical Papanicolaou (Pap) smears, evaluated using the criteria outlined recently, ${ }^{3-611}$ showed cytopathic changes induced by HPV. All patients were studied at the outpatient department of gynaecology and obstetrics, Kuopio University Central Hospital, Kuopio, Finland, at six month intervals, as described recently. ${ }^{14}$ At each attendance, the patient had a complete gynaecological examination including colposcopy; a directed punch biopsy specimen was taken if concomitant CIN lesions (HPV-CIN) had been identified from the primary Pap smear or in subsequent biopsies, or both. ${ }^{14}$ Thus two groups of patients were formed, those with HPV but not CIN (HPV-NCIN) who were studied by colposcopy and Pap smears, and those with HPV-CIN who

TABLE I Ages of 286 women studied prospectively for infection with human papillomavirus (HPV) and cervical intraepithelial neoplasia (CIN)

\begin{tabular}{ll}
\hline Age (years) & No $(\%)$ of women \\
\hline $15-19$ & $37(12 \cdot 9)$ \\
$20-24$ & $88(3 \cdot \cdot)$ \\
$25-29$ & $52(18 \cdot 2)$ \\
$30-34$ & $41(14 \cdot 3)$ \\
$35-39$ & $25(8 \cdot 7)$ \\
$40-44$ & $13(4 \cdot 5)$ \\
$45-49$ & $10(3 \cdot 5)$ \\
$50-54$ & $6(2 \cdot 1)$ \\
$55-59$ & $9(3 \cdot 2)$ \\
$60-64$ & $2(0 \cdot 7)$ \\
$65-69$ & $3(1 \cdot 1)$ \\
\hline
\end{tabular}

underwent additional punch biopsies. Table I shows the age distribution of these patients; the peak was between 20 and 24 years, and $61.9 \%$ of the women were aged under 30 . The mean (SD) follow up time was $16 \cdot 0(14 \cdot 2)$ months.

Whenever a punch biopsy was indicated, three samples of cervical tissue were removed; one was processed for routine light microscopy, one for electron microscopy, and one was frozen immediately for immunohistochemical analysis of local immunocompetent cell infiltrates. ${ }^{14}{ }^{32}$ In sections stained with haematoxylin and eosin, the morphology of the HPV lesions was analysed using the criteria outlined previously, ${ }^{3-611}$ and each lesion was classified as being in one of three categories: flat, inverted, or papillomatous condyloma. The grade of CIN was assessed using the commonly accepted criteria for CIN I, II, and III. On special occasions carcinoma in situ (CIS) was included as a separate category.

The fresh tissue samples were immediately frozen in isopenthane cooled with liquid nitrogen, and were stored at $-70^{\circ} \mathrm{C}$ until processed further. Cryostat sections $6 \mu \mathrm{m}$ thick were cut, and stained for B lymphocytes and $T$ lymphocyte subsets using the monoclonal antibodies and the avidin-biotin peroxidase complex (ABC) method. The following monoclonal antibodies were used: Leu-10 (BectonDickinson, Sunnyvale, California, USA), which is known to define B lymphocytes; OKT-3 (Ortho Immunobiology Ltd, Raritan, New Jersey, USA), which is known to react with all peripheral $T$ lymphocytes; OKT-4 (Ortho) for T inducer or helper cells; and OKT-8 for $\mathrm{T}$ suppressor or cytotoxic cells. ${ }^{33}$ Briefly, the $6 \mu \mathrm{m}$ cryostat sections were fixed in cold $\left(4^{\circ} \mathrm{C}\right)$ acetone for 10 minutes and dried at room temperature. The endogenous peroxidase activity was blocked by methanol-hydrogen peroxide solution. The sections were then incubated sequentially with appropriate dilutions of the following antisera: each of the monoclonal antibodies Leu-10, OKT-3, OKT-4, and OKT-8 for 15 minutes; biotinylated rabbit anti-mouse IgG (Vector Laboratories, Burlingame, California, USA) for 15 minutes; and avidin-horseradish peroxidase (Vector Laboratories) for another 15 minutes. The peroxidase reaction was developed for five minutes using diaminobenzidine (DAB) as substrate. The primary antibody was omitted from one negative control, and DAB substrate alone was applied to another to show the residual endogenous peroxidase activity.

Positive reactions for each monoclonal antibody were shown as a membrane or granular staining of lymphocytes in the subepithelial immunocompetent cell infiltrates and within the squamous epithelium (figs 1 and 2). The percentages of Leu- $10^{+}, \mathrm{OKT}_{-} 3^{+}$, $\mathrm{OKT}-4^{+}$, and $\mathrm{OKT}-8^{+}$cells in the lesions were 


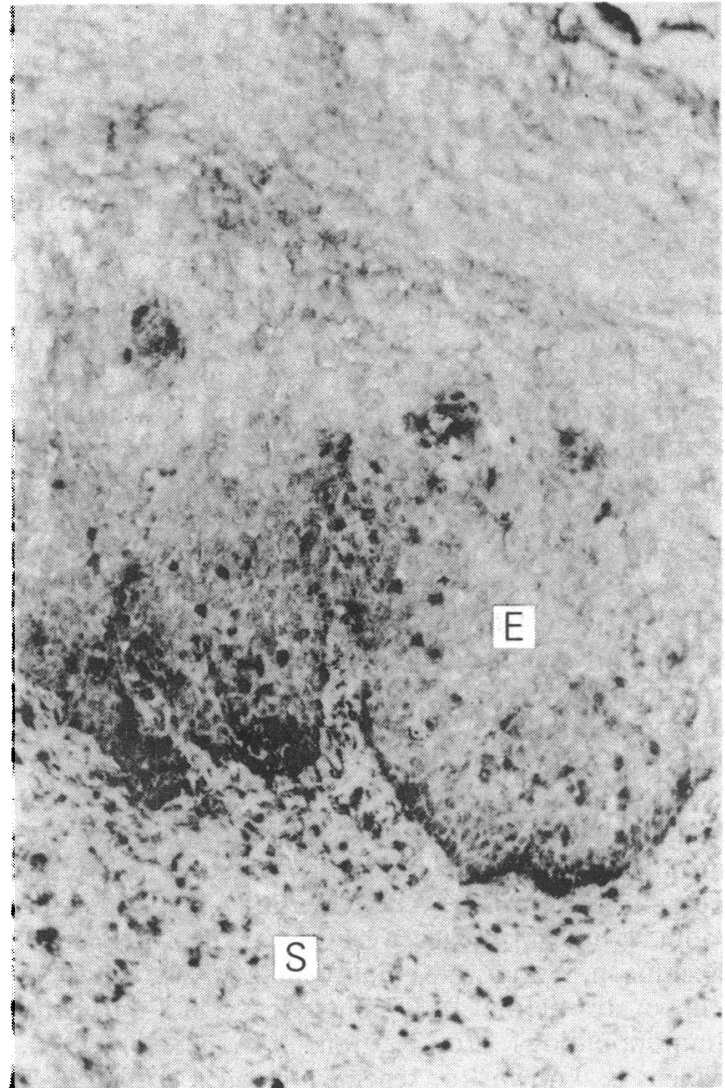

FIG 1 Low-power view of cervical HPV lesion stained with Leu-10 monoclonal antibody for $B$ lymphocytes. Most cells stain positive in both the stromal (S) infiltrate and within the squamous epithelium (E) (avidin-biotin peroxidase complex $(A B C)$ technique with Leu-10, original magnification $\times 100)$.

established by counting 200 cells at random in different sections of each lesion. The ratio of $\mathrm{OKT}-4^{+}$to OKT $-8^{+}$( $\mathrm{T}$ helper to $\mathrm{T}$ suppressor cells) was established in each specimen. The cell counting was completed in a blind manner by one of us (KS), who was not aware of the identity of the specimens at this stage of the study.

Student's $t$ test was applied for the statistical calculations where they are shown separately.

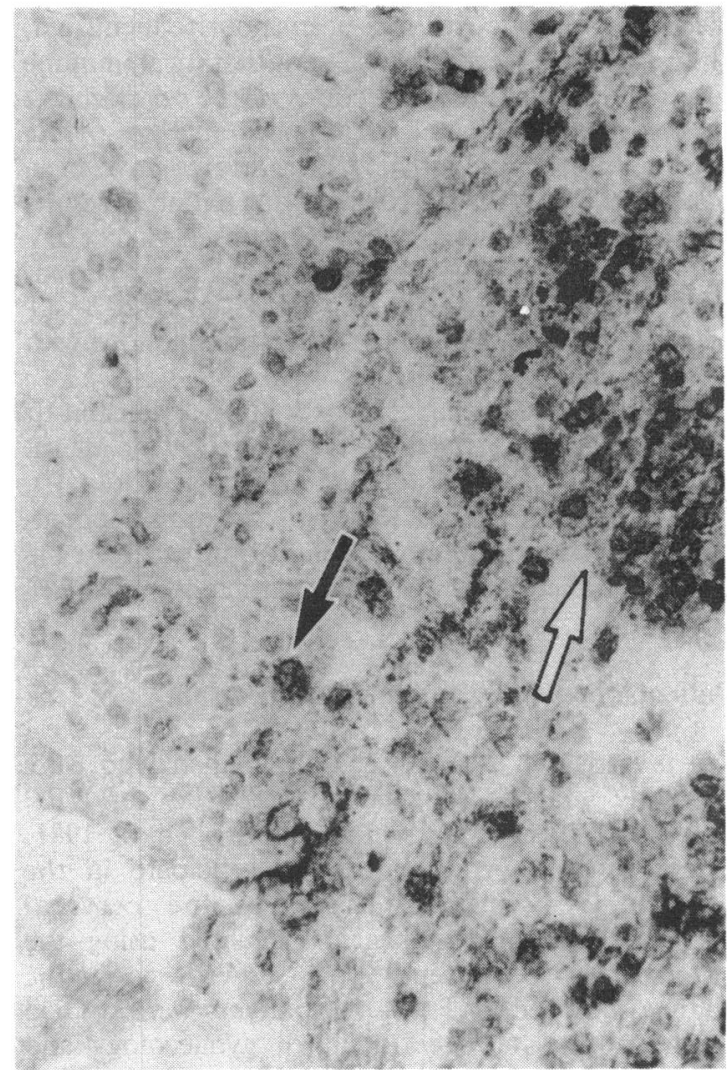

FIG $2 H P V$ lesion adjacent to the transformation zone stained with OKT-8 monoclonal antibody for $T$ suppressor or cytotoxic cells. Dense cluster of OKT-8+ cells present in stromal infiltrate (open arrow), and scattered $O K T-8+$ cells found within squamous epithelium (solid arrow) (avidin-biotin peroxidase complex $(A B C)$ technique with OKT-8, original magnification $\times 250$ ).

\section{Results}

Table II shows the percentages of $\mathrm{B}$ and $\mathrm{T}$ lymphocytes (Leu- $10^{+}$and $\mathrm{OKT}-3^{+}$) as well as $\mathrm{T}$ cell subsets $\left(\mathrm{OKT}-4^{+}, \mathrm{OKT}^{-8^{+}}\right)$in different types of HPV lesions. Only small fluctuations were found in the proportions of both $B$ and $T$ cells between the three types of condylomata, the ratio of $T$ helper to $T$

TABLE II B lymphocytes and $T$ cell subsets in different types of cervical human papillomavirus (HPV) lesions in 163 women

\begin{tabular}{|c|c|c|c|c|c|c|}
\hline \multirow{2}{*}{$\begin{array}{l}\text { Type of } \\
\text { HPV lesion }\end{array}$} & \multirow{2}{*}{$\begin{array}{l}\text { No of } \\
\text { patients }\end{array}$} & \multicolumn{4}{|c|}{ Mean (SE) No of cells reactive with: } & \multirow{2}{*}{$\begin{array}{l}\text { Mean (SE) ratio of } \\
\text { OKT-4 to OKT-8 cells }\end{array}$} \\
\hline & & $L E U-10$ & $O K T-3$ & $O K T-4$ & $O K T-8$ & \\
\hline $\begin{array}{l}\text { Flat } \\
\text { Papillomatous } \\
\text { Inverted } \\
\text { Normal }\end{array}$ & $\begin{array}{r}173 \\
10 \\
8 \\
72\end{array}$ & $\begin{array}{l}53 \cdot 2(1 \cdot 08) \\
52.9(2 \cdot 56) \\
48 \cdot 0(5 \cdot 88) \\
50 \cdot 3(2 \cdot 03)\end{array}$ & $\begin{array}{l}19 \cdot 7(0.67) \\
18.3(2 \cdot 06) \\
21.9(3 \cdot 75) \\
20.6(1 \cdot 12)\end{array}$ & $\begin{array}{r}8.6(0.38) \\
9.5(1.46) \\
11.3(1.87) \\
9.3(0.67)\end{array}$ & $\begin{array}{l}10.5(0.52) \\
12.2(2.03) \\
13.9(2.62) \\
10.6(0.86)\end{array}$ & $\begin{array}{l}1.12(0.08) \\
1.03(0.19) \\
1.05(0.29) \\
1.05(0.07)\end{array}$ \\
\hline
\end{tabular}


TABLE III Percentages of B lymphocytes and T cell subsets related to the grade of cervical intraepithelial neoplasia (CIN) associated with human papillomavirus (HPV) infection in 163 women

\begin{tabular}{|c|c|c|c|c|c|c|}
\hline \multirow{2}{*}{$\begin{array}{l}\text { Grade of CIN } \\
\text { associated with HPV }\end{array}$} & \multirow{2}{*}{$\begin{array}{l}\text { No of } \\
\text { biopsy } \\
\text { specimens }\end{array}$} & \multicolumn{4}{|c|}{ Mean (SE) No of cells reactive with: } & \multirow{2}{*}{$\begin{array}{l}\text { Mean (SE) ratio of } \\
O K T-4 \text { to OKT-8 cells }\end{array}$} \\
\hline & & $L E U-10$ & $O K T-3$ & $O K T-4$ & $O K T-8$ & \\
\hline $\begin{array}{l}\text { HPV-NCIN } \\
\text { HPV-CIN I } \\
\text { HPV-CIN II } \\
\text { HPV-CIN III } \\
\text { HPV-CIS }\end{array}$ & $\begin{array}{r}166 \\
62 \\
20 \\
12 \\
3\end{array}$ & $\begin{array}{l}52 \cdot 6(1 \cdot 23) \\
53 \cdot 2(1 \cdot 72) \\
50 \cdot 1(2 \cdot 81) \\
46 \cdot 2(4 \cdot 52) \\
55 \cdot 0(2 \cdot 52)\end{array}$ & $\begin{array}{l}19 \cdot 9(0 \cdot 71) \\
20 \cdot 1(1 \cdot 19) \\
18 \cdot 5(1 \cdot 58) \\
22 \cdot 6(2 \cdot 07) \\
18 \cdot 3(4 \cdot 42)\end{array}$ & $\begin{array}{r}8.9(0.41) \\
9.0(0.70) \\
8.3(0.91) \\
10.4(1.11) \\
6.0(1.53)\end{array}$ & $\begin{array}{l}10.5(0.57) \\
10.6(0.83) \\
12.5(1.40) \\
11.5(1.25) \\
12.7(6.68)\end{array}$ & $\begin{array}{l}1.14(0.08) \\
1.04(0.12) \\
0.91(0.21) \\
1.04(0.13) \\
0.67(0.16)\end{array}$ \\
\hline
\end{tabular}

HPV-NCIN = patients with HPV but not CIN.

CIS = carcinoma in situ.

suppressor cells being almost identical. The same held true of the biopsies showing a normal epithelium -that is, those in which viral changes had disappeared.

Table III shows the percentages of immunocompetent cells related to the grade of HPV-CIN. Only minor changes in percentages of $B$ and $T$ cells, and of their subsets were found between the different grades of HPV-CIN. There seemed, however, to be a slight tendency for the ratio of OKT $-4^{+}$to OKT $-8^{+}$ cells to decrease parallel with increasing severity of CIN, reaching the lowest values in HPV-CIS lesions ( $p<0.01$ between HPV-NCIN and HPV-CIS).

Table IV shows the relative numbers of different cells in relation to the intensity of the immunocompetent cell infiltrate. The percentage of B cells increased in parallel with the increasing intensity of the infiltrate. The same held true of the relative numbers of $T$ helper cells, leading to a rise in the ratio of $\mathrm{OKT}-4^{+}$to $\mathrm{OKT}-8^{+}$cells in moderate and intense infiltrates.

Table $\mathrm{V}$ summarises the percentages of types of immunocompetent cells in various age groups. The figures show that no clear cut age dependence exists for any of these cell types.

Table VI shows the percentages of the different types of immunocompetent cells related to the clinical course of the lesions. The relative numbers of OKT $-8^{+} \mathrm{T}$ cells rose in lesions that had progressed, when compared with those that had regressed or persisted. Thus the ratio of OKT $-4^{+}$to OKT $-8^{+}$cells seemed to be lowest (the only ratio below 1) in HPV lesions that had progressed clinically, and highest in those that had regressed, but the difference was not significant.

\section{Discussion}

Recent evidence from studies on the organisation of human lymphatic tissues in different anatomical sites suggests a unifying concept of skin associated lymphoid tissue (SALT) and mucosal associated lymphoid tissue (MALT) to explain the complex interplay of immune functions required to cover the special demands of continuous antigenic stimuli. ${ }^{34} 35$ According to the SALT/MALT concept, the local microenvironment is capable on its own of accepting, processing, and presenting the diversity of antigens conditioned by the keratinocytes, Langerhans cells, and immunocompetent lymphocytes, including their subsets. ${ }^{34}{ }^{35}$ The dynamic regulatory balance between the different cell types and their subsets is a prerequisite of an appropriate immune reactivity in situ, which is designed to provide the skin and mucosal sites with immune surveillance against developing neoplasms and infections with intracellular pathogens, such as viruses.

According to the SALT/MALT concept, it seems feasible to assess whether (and how effectively) such local immune mechanisms can resist and modify the course of infections with HPV. Reports on the rejection of cutaneous warts conditioned by the in situ immunocompetent cells ${ }^{1721-2428}$ are possible indicators of such effectiveness. On the other hand, depletion of cell mediated immune mechanisms and immunosuppression seem to be associated with generalised infections with HPV and often with malignant transformation. 15-20 262736 Morphologically different patterns of reaction found in plane and common skin warts (due to different types of HPV) in regression ${ }^{1721232436}$ show some

TABLE IV Numbers of B cells and $T$ cells subsets related to intensity of immunocompetent cell infiltrate in 163 women

\begin{tabular}{|c|c|c|c|c|c|c|}
\hline \multirow{2}{*}{$\begin{array}{l}\text { Intensity of } \\
\text { infiltrate }\end{array}$} & \multirow{2}{*}{$\begin{array}{l}\text { No of } \\
\text { biopsy } \\
\text { specimens }\end{array}$} & \multicolumn{4}{|c|}{ Mean (SE) No of cells reactive with: } & \multirow{2}{*}{$\begin{array}{l}\text { Mean (SE) ratio of } \\
O K T-4 \text { to OKT-8 cells }\end{array}$} \\
\hline & & $L E U-10$ & $O K T-3$ & $O K T-4$ & $O K T-8$ & \\
\hline $\begin{array}{l}\text { Weak } \\
\text { Moderate } \\
\text { Intense }\end{array}$ & $\begin{array}{r}116 \\
82 \\
65\end{array}$ & $\begin{array}{l}50 \cdot 3(1 \cdot 29) \\
52 \cdot 7(1 \cdot 54) \\
52 \cdot 8(1 \cdot 91)\end{array}$ & $\begin{array}{l}19 \cdot 2(0 \cdot 81) \\
20 \cdot 2(0 \cdot 98) \\
20 \cdot 1(1 \cdot 08)\end{array}$ & $\begin{array}{l}8 \cdot 2(0.47) \\
9 \cdot 5(1 \cdot 54) \\
9 \cdot 9(0.68)\end{array}$ & $\begin{array}{r}9.5(0.59) \\
11.9(0.74) \\
11.6(0.91)\end{array}$ & $\begin{array}{l}1 \cdot 00(0 \cdot 05) \\
1 \cdot 15(0 \cdot 14) \\
1 \cdot 17(0 \cdot 12)\end{array}$ \\
\hline
\end{tabular}


TABLE $\mathrm{V}$ Age dependence of the percentages of $B$ cells and $T$ cell subsets in 163 women with cervical human papillomavirus (HPV) lesions

\begin{tabular}{|c|c|c|c|c|c|c|}
\hline \multirow{2}{*}{$\begin{array}{l}\text { Age } \\
\text { (years) }\end{array}$} & \multirow{2}{*}{$\begin{array}{l}\text { No of } \\
\text { patients }\end{array}$} & \multicolumn{4}{|c|}{ Mean (SE) No of cells reactive with: } & \multirow{2}{*}{$\begin{array}{l}\text { Mean (SE) ratio of } \\
O K T-4 \text { to OKT-8 cells }\end{array}$} \\
\hline & & $L E U-10$ & $O K T-3$ & $O K T-4$ & $O K T-8$ & \\
\hline $15-19$ & 18 & $46 \cdot 1(3 \cdot 99)$ & $23 \cdot 9(2 \cdot 78)$ & $10 \cdot 4(1 \cdot 58)$ & $10.9(1.58)$ & $1 \cdot 19(0 \cdot 22)$ \\
\hline $20-24$ & 51 & $53 \cdot 2(1 \cdot 77)$ & $20 \cdot 1(1 \cdot 12)$ & $9 \cdot 1(0.69)$ & $10.4(0.75)$ & $0.98(0.08)$ \\
\hline $25-29$ & 33 & $55.0(2.55)$ & $20 \cdot 0(1 \cdot 61)$ & $9.5(0.86)$ & $8 \cdot 9(1 \cdot 00)$ & $1 \cdot 16(0.08)$ \\
\hline $30-34$ & 18 & $57 \cdot 5(2 \cdot 79)$ & $17 \cdot 9(1 \cdot 72)$ & $7 \cdot 0(0 \cdot 68)$ & $10 \cdot 6(1 \cdot 39)$ & $0.87(0.14)$ \\
\hline $35-39$ & 17 & $49.9(3.01)$ & $22 \cdot 8(2 \cdot 65)$ & $7 \cdot 1(1 \cdot 03)$ & $10 \cdot 6(1.89)$ & $0.86(0.11)$ \\
\hline $40-44$ & 8 & $52 \cdot 8(6 \cdot 27)$ & $19.4(3.49)$ & $12 \cdot 1(2 \cdot 67)$ & $16.5(3.54)$ & $1.58(0.92)$ \\
\hline $45-49$ & 3 & $53.7(3.85)$ & $18 \cdot 0(1 \cdot 00)$ & $4 \cdot 7(1 \cdot 77)$ & $9 \cdot 3(2 \cdot 19)$ & $0.49(0.12)$ \\
\hline $50-54$ & 5 & $61 \cdot 8(7 \cdot 94)$ & $19 \cdot 6(4 \cdot 57)$ & $9 \cdot 2(2 \cdot 49)$ & $11 \cdot 2(2 \cdot 87)$ & $0.87(0.15)$ \\
\hline $55-59$ & 8 & $58 \cdot 8(2 \cdot 91)$ & $19 \cdot 6(1 \cdot 73)$ & $7 \cdot 5(1 \cdot 05)$ & $12 \cdot 3(2 \cdot 95)$ & $0.84(0.19)$ \\
\hline $60-64$ & 1 & $40 \cdot 0$ & $21 \cdot 0$ & $12 \cdot 0$ & $19 \cdot 0$ & 0.63 \\
\hline $65-69$ & 1 & $56 \cdot 0$ & $24 \cdot 0$ & $12 \cdot 0$ & $12 \cdot 0$ & $1 \cdot 00$ \\
\hline
\end{tabular}

evidence that the type of local reaction might depend on the type of HPV. ${ }^{17}$ Practically no such data are available on HPV lesions of the cervix, which are mostly caused by HPV 6,10 , and 11 , although a certain percentage of them seem to regress even within a short period of follow up. ${ }^{14}$

In the healthy adult uterine cervix, Langerhans cells and $B$ and $T$ lymphocytes have been found in the subepithelial infiltrate, as well as within the squamous epithelium. ${ }^{30} \mathrm{~T}$ suppressor cells outnumbered $\mathrm{T}$ helper cells within the epithelium in these biopsy specimens (from a total of six patients only), the reverse being true in the subepithelial infiltrates. ${ }^{30}$ Squamous epithelium infected by HPV contained fewer $\mathrm{T}$ cells and Langerhans cells than were found in healthy cervical epithelium, ${ }^{31}$ although no data were given on $B$ cells and $T$ cell subsets in such infiltrates associated with HPV infections. ${ }^{31}$ Such an infiltrate containing both $\mathrm{OKT}-4^{+}$and OKT $-8^{+} \mathrm{T}$ cells was, however, recently reported in the three genital warts included in a study of skin warts. ${ }^{29}$ This agrees with the data provided by the first systematic study on HPV lesions of the cervix using the histochemical acid $\alpha$-naphthyl acetate esterase (ANAE) technique to define $B$ and $T$ lymphocytes and mononuclear phagocytes (MPS cells). ${ }^{32}$ In that study, B lymphocytes far outnumbered T cells and MPS cells both in infections with HPV and in CIN lesions. This was confirmed by the study published here, in which Leu- $10^{+}$B cells predominated over OKT $-3^{+} \mathrm{T}$ cells in all types of infection with HPV (table II).
In previous studies, the increase in proportions of $T$ cells parallelled an increasing grade of HPV-CIN, ${ }^{14} 32$ which was attributed to a relative increase in the numbers of $\mathrm{T}$ suppressor cells. ${ }^{32}$ This was partly confirmed by the results presented here (table III), which showed the highest percentage $(22.6 \%)$ of OKT $-3^{+}$T cells in HPV-CIN III lesions, although the difference from that in HPV-NCIN lesions $(19 \cdot 9 \%)$ was not significant. In the same way, the percentage of OKT-8 $8^{+}$cells was lowest in HPVNCIN lesions and highest in HPV-CIS lesions. This seems to confirm the previous suggestions concerning the relative increase of $T$ suppressor cells in HPVCIN lesions, ${ }^{32}$ which led to a lower ratio of OKT-4+ to OKT $-8^{+}$cells in HPV-CIS compared with that in HPV-NCIN ( $p<0 \cdot 01)$.

The increase in relative proportions of $B$ cells parallelled the increasing intensity of the local infiltrate (table IV). The same is true of the relative increase of $T$ helper cells, which led to a parallel rise in the ratio of OKT $-4^{+}$to OKT-8+ cells. This agreed with the observations made in the normal cervix, in which dense subepithelial infiltrates were shown to have a preponderance of OKT $-4^{+}$cells over OKT $-8^{+}$ cells, ${ }^{30}$ thus reflecting an enhanced humoral immune reactivity in these dense infiltrates. Consistent with the data on many human malignancies that an intense stromal inflammatory cell reaction is a sign of favourable outlook, the increased ratio of OKT $-4^{+}$ to $\mathrm{OKT}-8^{+}$cells in this study could also be regarded as a favourable sign, as the highest ratio of OKT- $4^{+}$ to $\mathrm{OKT}-8^{+}$cells was found in HPV lesions that

TABLE VI Percentages of B lymphocytes and T cell subsets related to the clinical course of cervical (HPV) lesions in 163 women

\begin{tabular}{|c|c|c|c|c|c|c|}
\hline \multirow{2}{*}{$\begin{array}{l}\text { Clinical } \\
\text { course }\end{array}$} & \multirow{2}{*}{$\begin{array}{l}\text { No }(\%) \text { of } \\
\text { patients }\end{array}$} & \multicolumn{4}{|c|}{ Mean (SE) No of cells reactive with: } & \multirow{2}{*}{$\begin{array}{l}\text { Mean (SE) ratio of } \\
O K T-4 \text { to OKT-8 cells }\end{array}$} \\
\hline & & $L E U-10$ & $O K T-3$ & $O K T-4$ & $O K T-8$ & \\
\hline $\begin{array}{l}\text { Regressed } \\
\text { Persisted } \\
\text { Progressed }\end{array}$ & $\begin{array}{l}47(28 \cdot 8) \\
85(52 \cdot 1) \\
31(19 \cdot 1)\end{array}$ & $\begin{array}{l}55 \cdot 5(2 \cdot 37) \\
52 \cdot 5(1 \cdot 41) \\
52 \cdot 5(2 \cdot 26)\end{array}$ & $\begin{array}{l}21 \cdot 1(1 \cdot 51) \\
20 \cdot 1(0 \cdot 99) \\
21 \cdot 2(1 \cdot 42)\end{array}$ & $\begin{array}{l}8.5(0.79) \\
9 \cdot 1(0.56) \\
8.9(0.78)\end{array}$ & $\begin{array}{r}9.2(0.95) \\
11 \cdot 0(0.71) \\
11 \cdot 2(1.09)\end{array}$ & $\begin{array}{l}1.07(0.08) \\
1.04(0.10) \\
0.93(0.09)\end{array}$ \\
\hline
\end{tabular}


regressed during follow up (table VI).

Of the 163 cervical HPV lesions from which data on biopsies and $\mathrm{ABC}$ staining were available, 47 $(28.8 \%)$ regressed, $85(52 \cdot 1 \%)$ persisted, and 31 $(19 \cdot 1 \%)$ progressed during the mean (SD) follow up period of $16(14)$ months. The results presented here show only minor fluctuations of the numbers of immunocompetent cells in lesions with different clinical courses (table VI). There seemed, however, to be a relative increase in OKT $-8^{+}$cells in order of regressing, persistent, and progressing lesions, which had also been shown in the preliminary study based on a small number of patients and a short follow up. ${ }^{14}$ Thus it seems that in HPV lesions of the cervix the shift in local immunoregulatory cell balance in favour of OKT $-8^{+} \mathrm{T}$ cells is associated with clinical progression of the lesions. Consistent with the data available on other immunologically conditioned disorders (including AIDS) the lowered ratio of $\mathrm{OKT}-4^{+}$to OKT $-8^{+}$cells is probably due to an inappropriate increase of $T$ suppressor cells in relation to the number of $T$ helper cells. The latter, in fact, seemed to remain at a relatively constant level irrespective of the clinical course of the HPV lesions in this study. Until we have means available to distinguish between $T$ suppressor and $T$ cytotoxic cells (both $\mathrm{OKT}-8^{+}$), however, this interpretation is made with caution.

In conclusion, the present study lends support to the concept that a local immunocompetent cell infiltrate is common in cervical HPV lesions. The constituents of this infiltrate probably participate in the immune reactions to infection with HPV, as suggested by the fluctuations in their numbers related to the grade of CIN associated with HPV and to the intensity of the infiltrate proper, but not related to the age of the patients. Furthermore, the ratio of OKT $-4^{+}$to OKT $-8^{+}$cells seems to be subjected to changes related to the clinical behaviour of HPV lesions, progression being associated with an inappropriate increase of OKT-8 ${ }^{+} \mathrm{T}$ suppressor cell activity. The value of these observations will be shown by the extension for many years of the current follow up study.

This work was supported in part by a research grant from the Medical Council of the Academy of Finland (07/014), and in part by a research grant from the Finnish Cancer Society. The skillful technical assistance of Mrs Heli Eskelinen and Miss Ritva Savolainen is gratefully acknowledged.

\section{References}

1. Fu YS, Reagan JW, Richart RM. Precursors of cervical cancer. Cancer Survey 1983; 2:359-82.

2. Fu YS, Braun L, Shah KV, Lawrence WD, Robboy SJ. Histologic, nuclear DNA and human papillomavirus studies of cervical condylomas. Cancer 1983;52:1705-11.
3. Purola EE, Halila H, Vesterinen E. Condyloma and cervical epithelial atypias in young women. Gynecol Oncol 1983;16: 34-40.

4. Syrjänen KJ. Current views on the condylomatous lesions in uterine cervix and their possible relationship to cervical squamous cell carcinoma. Obstet Gynecol Surv 1980;35: 685-94.

5. Syrjänen KJ. Human papillomavirus (HPV) lesions in association with cervical dysplasias and neoplasias. Obstet Gynecol 1983;62:617-22.

6. Syrjänen KJ. Current concepts on human papillomavirus (HPV) infections in the genital tract and their relationship to intraepithelial neoplasia and squamous cell carcinoma. Obstet Gynecol Surv 1984;39:252-65.

7. de Brux J, Orth G, Croissant O, Cochard B, Ionesco M. Lesions condylomateuses du col uterin: evolution chez 2466 patientes. Bull Cancer (Paris) 1983; 70:410-22.

8. Dürst M, Gissmann L, Ikenberg H, zur Hausen H. A papillomavirus DNA from a cervical carcinoma and its prevalence in cancer biopsy samples from different geographic regions. Proc Natl Acad Sci USA 1983;80:3812-4.

9. Fletcher $\mathbf{S}$, Norval M. On the nature of the deep cellular disturbances in human papilloma virus infection of the squamous cervical epithelium. Lancet 1983; ii:546-9.

10. Guillet G, Braun L, Shah K, Ferenczy A. Condylomes cervicaux et dysplasie: confrontation histologique et virologique a propos de 100 observations. Ann Dermatol Venereol 1983; 110:43-51.

11. Reid R, Crum CP, Herschman BR, et al. Genital warts and cervical cancer. III. Subclinical papillomaviral infection and cervical neoplasia are linked by a spectrum of continuous morphologic and biologic change. Cancer 1984;53:943-53.

12. Schmauz R, Claussen CP, Cordes B, Owor R. Condylomata acuminata and their possible relation to cancer of the uterine cervix. Case report and geographic observations. Acta Cytol (Baltimore) 1983; 27:533-9.

13. Singer A, Walker PG, McCance DJ. Genital wart virus infections: nuisance or potentially lethal? Br Med J 1984; 288: 735-7.

14. Syrjänen $K J$, Väyrynen $M$, Castren $O$, Mäntyjärvi R, Yliskoski $M$. The relation between the type of immunoreactive cells found in human papillomavirus (HPV) lesions of the uterine cervix and the subsequent behaviour of these lesions. Arch Gynecol 1984; 234: 189-96.

15. Barnett N, Mak H, Winkelstein JA. Extensive verrucosis in primary immunodeficiency diseases. Arch Dermatol 1983; 119: 5-7.

16. Glinski $\mathrm{W}$, Obalek $\mathrm{S}$, Jablonska $\mathrm{S}$, Orth $\mathrm{G}$. $\mathrm{T}$ cell defect in patients with epidermodysplasia verruciformis due to human papillomavirus type 3 and 5. Dermatologica 1981;162:141-7.

17. Jablonska S, Orth G, Lutzner MA. Immunopathology of papillomavirus-induced tumors in different tissues. Springer Semin Immunopathol 1982;5:33-62.

18. Lutzner MA, Orth G, Dutronquay V, Ducasse M-F, Kreis H Crosnier J. Detection of human papillomavirus type 5 DNA in skin cancers of an immunosuppressed renal allograft recipient. Lancet 1983; ii: $422-4$.

19. Schneider V, Kay S, Lee HM. Immunosuppression as a highrisk factor in the development of condyloma acuminatum and squamous neoplasia of the cervix. Acta Cytol 1983;27:220-4.

20. Shokri-Tabibzadeh S, Koss LG, Molnar J, Romney S. Association of human papillomavirus with neoplastic processes in the genital tract of four women with impaired immunity. Gynecol Oncol 1981: 12: 129-40.

21 Kossard S, Xenias SJ, Palestine RF, Scheen SR, Winkelmann RK. Inflammatory changes in verruca vulgaris. J Cutan Pathol 1980; 7:217-21

22. Morison WL. Cell-mediated immune responses in patients with warts. Br J Dermatol 1975;93:553-6.

23. Oguchi M, Komura J, Tagami H, Ofuji S. Ultrastructura studies of spontaneously regressing plane warts. Macrophages attack verrucaepidermal cells. Arch Dermatol Res 1981; 270:403-11.

24. Tagami $\mathbf{H}$, Oguchi M, Ofuji S. The phenomenon of spontaneous regression of numerous flat warts: immunohistological studies. Cancer 1980; 45:2557-63.

25. Baird PJ. Serological evidence for the association of papillomavirus and cervical neoplasia. Lancet 1983; i: 17-8.

26. Chretien JH, Esswein JG, Garagusi VF. Decreased T cell levels in patients with warts. Arch Dermatol 1978; 114:213-5. 
27. Kienzler JL, Lemoine MTH, Orth G, et al. Humoral and cellmediated immunity to human papillomavirus type 1 (HPV-1) in human warts. Br J Dermatol 1983; 108:665-72.

28. Viac J, Staquet MJ, Miguet M, Chabanon M, Thivolet J. Specific immunity to human papilloma virus (HPV) in patients with genital warts. British Journal of Venereal Diseases 1978; 54: $172-5$.

29. Chardonnet $Y$, Beauve $P$, Viac J, Schmitt D. T cell subsets and Langerhans cells in wart lesions. Immunol Lett 1983;6: 191-6.

30. Morris HHB, Gatter KC, Stein H, Mason Y. Langerhans cells in human cervical epithelium: an immunohistological study. $\mathrm{Br}$ J Obstet Gynaecol 1983;90:400-11.

31. Morris HHB, Gatter KC, Sykes G, Casemore V, Mason DY. Langerhans cells in human cervical epithelium: effects of wart virus infection and intraepithelial neoplasia. $\mathrm{Br} J$ Obstet Gynaecol 1983;90:412-20.
32. Syrjänen KJ. Immunocompetent cells in uterine cervical lesions of human papillomavirus origin. Gynecol Obstet Invest 1983; 16:327-40.

33. Kung PC, Goldstein G, Reinherz EL, Schlossman SF. Monoclonal antibodies defining distinctive human T-cell surface antigens. Science 1979; 206:347-52.

34. Poulter LW. Antigen presenting cells in situ: their identification and involvement in immunopathology. Clin Exp Immunol 1983;53:513-20

35. Streilein JW. Skin-associated lymphoid tissue (SALT): origins and functions. $J$ Invest Dermatol 1983;80: 12s-16s.

36. Obalek S, Glinski W, Haftek M, Orth G, Jablonska S. Comparative studies on cell-mediated immunity in patients with different warts. Dermatologica 1980; 161:73-83. 